council), which was set up in 1949, and in its short life was intended to function both as a funding agency and a central strategic advisory board for science. But this body failed to win widespread support, as it conflicted with the concern of German intellectuals, acutely sensitive to the dangers of concentration of power, that excessive federal influence over cultural matters should be avoided. It was transformed in the early 1950 s into the Deutsche Forschungsgemeinschaft (DFG), today's funding agency for university research.

This wariness of centralized power remains the hallmark of German research. The German basic law, drawn up in 1949, states that "Art, science, research and teaching are free", and to ensure this, the Länder were given extensive powers in cultural affairs. But recognizing that it might not in practice be possible for research to have no central coordination at all, another article in the basic law opened the door to joint responsibility of federal and Länder governments for research

But this door remained closed for years until two practical issues forced it to open: the inability of individual Länder to afford the large research facilities required to develop nuclear power, and the fact that poorer Länder were losing out to the richer Länder in terms of scientific development.

After the war, Germany was forbidden by the allies to undertake nuclear research. Indeed, the constitution precludes the establishment of a central atomic agency, as exists in most other countries. But in the 1950 s Germany became as keen as others to develop cheap nuclear power, and the individual Länder could not afford to do this on their own.

As its first venture into the research arena, the federal government established a 'ministry for atomic questions' in 1955. Five national research centres concerned with nuclear research were rapidly set up. There are now 16 national research centres in Germany, and the political influence of the federal government is strongly felt, and resented, by scientists at the centres. They have come under attack in the past decade from the government which, as their paymaster, has demanded greater efficiency and closer collaboration with industry. The DFG and the MPS have more recently lent their support to the centres in their fight to ward off attempts to orientate their research to the needs of industry.

The issue of unequal development of research in the Länder has been addressed by a series of agreements from 1956 onwards, in which funding for research establishments is shared between federal and Länder governments according to agreed formulae.

The legacy of the war is still felt in the university sector. During the fascist years, the universities lost their traditional autonomy, and after the war they successfully fought to regain it. Federal influence is now

\title{
United Kingdom: promises, promises
}

London. In 1945, science in Britain was enjoying a peak of popularity that it has achieved neither before nor since. The British public had already been made aware of the contributions of scientists to a string of discoveries and inventions from penicillin to radar - that had helped win the war.

At the same time, the intellectual freedom enjoyed by the research community was portrayed as a cultural ideal that contrasted sharply with the rigid ideology that had shackled Nazi researchers. "Never hasscience stood so high in public esteem" wrote Nature in May 1945.

This acclaim was reflected in the supreme self-confidence with which scientists faced the task of re-building Britain's - and Europe's - economic base. Those such as the crystallographer J. D. Bernal, whose calls in the 1930 s for science to serve social ends had been viewed sceptically because of their links to socialist pro-grammes, now found their ideas had become part of the mainstream. As one historian puts it. "Having won the war, scientists were now going to win the peace".

At least four separate strands of the strategy for this debated at length during that period have made their mark over the intervening 50 years. Perhaps the most significant has been the political backing for links between science and production that has led to the growth of
Britain's science-based industries. The seeds of today's Technology Foresight programme for example can be seen in the debate over the need for strategic research priorities that took place in the columns of Nature and elsewhere.

A second, complementary, strand was the emphasis on the social value of basic research, and the need to respect the open communication of ideas. Britain had already had its own version of the Bush report (see page 5) in the work of the so-called Barlow committee of 1943.

A third element was the concept of planning for, through and by science. Debate at the time, reflected in Nature editorials, expressed a firm belief, rarely heard today, that rational planning was the key to the future health of all industrial economies. The planning failures of the 1960 s and 1970 s were still to come.

Perhaps the biggest gap between hopes and reality has been in the social status of science and scientists. "In the intellectual sense it is amazing what has been achieved in the past 50 years; but that increased knowledge has also led to a loss of sympathy, partly because of the failure of many scientists to explain their activities adequately," says Lord Flowers, former vice-chancellor of the University of London. Bernal, a great popularizer himself, would have shared Flowers' disappointment. felt only through support for university building and equipping, whose costs are shared, again to avoid disadvantaging the poorer Länder. But cracks in this system are also appearing, as the federal government now wants to cap funding to save money.

Strong decentralization has meant that Germany, rather than having a few central bodies controlling research strategy, has many forces whose views have to be juggled. Coordination at federal level is achieved through the science council, the Wissenschaftsrat, and the Bund-Länder Kommission (BLK), a political body that mediates between federal and Länder governments on cultural affairs.

This process has also recently been making itself felt in the former East Germany. The post-war development of science in the east was quite different from that in the west. Based on the Soviet model, research was removed from universities and placed in the centrally controlled institutes of the Academy of Sciences. Science suffered from tight political control, as well as the isolation from advances in the west.
Since reunification five years ago, western Germany has insisted on remodelling east German science in its own image, warts and all. The process of weeding out communists from the universities and research institutes was not as harsh as the denazification process overseen by the Allied forces immediately after the war (when, for example, 80 per cent of staff were sacked from the University of Munich, in the US sector). But the process has been painful, as has been getting used to a funding system based on scientific merit rather than political support.

One element - bureaucracy - that characterized both west and east has not disappeared. Decisions require consensus between all parties, including each Land. The decision-making process is therefore slow, cumbersome and compromise-orientated. But most Germans feel this process a small price to pay for the security that a pluralistic society provides. And most would also acknowledge that it has helped protect basic research against the attacks experienced in other industralized nations.

Alison Abbott 